\title{
Tachykinin-Related Peptide and GABA-Mediated Presynaptic Inhibition of Crayfish Photoreceptors
}

\author{
Raymon M. Glantz, ${ }^{1}$ Clyde S. Miller, ${ }^{1}$ and Dick R. Nässel ${ }^{2}$ \\ ${ }^{1}$ Department of Biochemistry and Cell Biology, Rice University, Houston, Texas 77251, and 2Department of Zoology, \\ Stockholm University, Stockholm, Sweden
}

\begin{abstract}
Off-axis illumination elicits lateral inhibition at the primary visual synapse in crustacea and insects. The evidence suggests that the inhibitory action is presynaptic (i.e., on the photoreceptor terminal) and that the amacrine neurons of the lamina ganglionaris (the first synaptic layer) may be part of the inhibitory pathway. The neurotransmitters and the synaptic mechanisms are unknown. We show by immunocytochemistry that GABA and a tachykinin-related peptide (TRP) are localized in the amacrine neurons of the crayfish lamina ganglionaris. Indirect evidence suggests that GABA and TRP may be colocalized in these neurons. The extensive processes of the amacrine neurons occupy lamina layers containing the terminals of photoreceptors. Application of exogenous GABA and TRP to photoreceptor terminals produces a short-latency, dose-dependent
\end{abstract}

hyperpolarization with a decay time constant on the order of a few seconds. TRP also exhibits actions that evolve over several minutes. These include a reduction of the receptor potential (and the light-elicited current) by $\sim 40 \%$ and potentiation of the action of GABA by $\sim 100 \%$. The mechanisms of TRP action in crayfish are not known, but a plausible pathway is a TRPdependent elevation of intracellular $\mathrm{Ca}^{2+}$ that reduces photoreceptor sensitivity in arthropods. Although the mechanisms are not established, the results indicate that in crayfish photoreceptors TRP displays actions on two time scales and can exert profound modulatory control over cell function.

Key words: tachykinin; photoreceptor; lateral inhibition; GABA; visual transduction; presynaptic inhibition; crayfish; invertebrate
Lateral inhibition is a prominent feature of the peripheral visual circuits of both vertebrates and arthropods in which it functions in both contrast enhancement and gain control. In vertebrate retina, lateral inhibition is mediated by horizontal cells that feedback a sign-inverted signal to receptor terminals (Attwell et al., 1983). In arthropods the mechanisms of lateral inhibition are still unresolved, but the inhibitory action seems to be on the presynaptic side of the primary synapse (photoreceptor to monopolar cell) (Wang-Bennett and Glantz, 1987; Laughlin and Osorio, 1989). In crayfish monopolar cells subjected to inhibitory visual stimuli, the light response and the input conductance decline in parallel. Furthermore, there is suggestive evidence that the amacrine neurons of the first synaptic region, the lamina, may be part of the inhibitory feedback pathway (Hamori and Horridge, 1966; Strausfeld and Campos-Ortega, 1977; Glantz and Bartels, 1994).

To identify the neurotransmitters that mediate lateral inhibition, we examined the cellular localization of GABA and a tachykinin-related peptide (TRP) and tested their actions on photoreceptor terminals. GABA is an obvious transmitter candidate because of its ubiquitous role in presynaptic inhibition in the crayfish nervous system (Takeuchi and Takeuchi, 1966; Kennedy

\footnotetext{
Received Oct. 12, 1999; revised Dec. 8, 1999; accepted Dec. 10, 1999.

This work was supported by the National Science Foundation Grant IBN-9807548 and by the National Library of Medicine Fellowship 1T15LM07093. D.R.N. was supported by the Swedish Natural Science Research Council (NFR). The technical assistance of Anne Karlsson is gratefully acknowledged. We thank Dr. M. Eckert (University of Jena) for the supply of GABA antiserum. We also thank the Rice University Keck Center for Computational Biology for their support and the staff of Friday Harbor Laboratories, University of Washington, for their hospitality and material assistance.

Correspondence should be addressed to Dr. R. M. Glantz, Department of Biochemistry and Cell Biology, Rice University, P.O. Box 1892, Houston, TX 77251. E-mail: rmg@bioc.rice.edu.

Copyright (C) 2000 Society for Neuroscience $\quad 0270-6474 / 00 / 201780-11 \$ 15.00 / 0$
}

et al., 1980; Glantz et al., 1985; Cattaert et al., 1994). TRP is considered because a substance P-like peptide is present in amacrine neurons of lobster lamina (Mancillas et al., 1981). Furthermore, substance $\mathrm{P}$ functions in visual processing in vertebrate retina (see Karten and Brecha, 1980; Zalutsky and Miller, 1990; Casini et al., 1997; Cuenca and Kolb, 1998) where it is localized to specific types of amacrine and ganglion cells.

Peptides with resemblance to tachykinins, TRPs, have been isolated from insects (see Schoofs et al., 1993; Nässel, 1999) and more recently from two crustaceans, the crab Cancer borealis and the shrimp Penaeus vannmei (Christie et al., 1997; Nieto et al., 1998). The presence of endogenous TRPs in the brain of the crayfish Pacifastacus leniusculus used in the present study has been indicated previously by immunocytochemistry and analysis of tissue extract by HPLC combined with radioimmunoassay using an antiserum to a locust TRP (Johansson et al., 1999). Because we now know that the TRP antiserum and monoclonal antibodies to substance P label the same neurons in crustaceans (Blitz et al., 1995; Johansson et al., 1999), it is suggestive that the substance P-like immunoreactivity described previously in lobster amacrine neurons (Mancillas et al., 1981; Fingerman et al., 1985) represents native TRP.

In this report we show GABA, TRP, and substance P immunoreactivity in amacrine cells of the lamina ganglionaris of the crayfish $P$. leniusculus. The amacrine cell neurites arborize in lamina regions containing photoreceptor terminals, as might be expected of a component of the lateral inhibitory pathway. Furthermore, exogenous GABA and TRP have functional actions consistent with their possible roles in presynaptic inhibition of the primary visual synapse. Both agents produce rapid and dosedependent hyperpolarizations of photoreceptor terminals. Additionally, TRP slowly (over several minutes) diminishes the pho- 
toreceptor's light-activated current and increases the magnitude of the GABA-elicited response.

\section{MATERIALS AND METHODS}

Animals. The crayfish $P$. leniusculus were purchased from suppliers in California and Stockholm.

Immunocytochemistry. The production of rabbit antiserum to the locust tachykinin-related peptide locustatachykinin-I (LomTK-I) has been described previously (Nässel, 1993). The antiserum specificity was characterized on insect and crustacean tissue previously (Nässel, 1993; Lundquist et al., 1994; Blitz et al., 1995; Christie et al., 1997; Johansson et al., 1999). A rat monoclonal antibody to the vertebrate tachykinin substance P (see Cuello et al., 1979) was purchased from Accurate Chemicals (Westbury, NY). The immunoreactive properties of this antibody on crustacean tissue have been characterized by Goldberg et al. (1988), Sandeman et al. (1990), and Blitz et al. (1995). The well characterized rabbit antiserum to GABA (see Füller et al., 1989) was kindly provided by Dr. M. Eckert (University of Jena, Jena, Germany).

For peptide immunocytochemistry (ICC) optic lobes were rapidly dissected in saline and fixed in $4 \%$ paraformaldehyde in $0.1 \mathrm{M}$ sodium phosphate buffer. For GABA ICC the dissected lobes were fixed in a mixture of $5 \mathrm{ml}$ of glutaraldehyde $(25 \%), 15 \mathrm{ml}$ of saturated aqueous picric acid, and $0.1 \mathrm{ml}$ of glacial acetic acid (Schot et al., 1981). In both cases fixation was for a minimum of $4 \mathrm{hr}$ at $4^{\circ} \mathrm{C}$. After fixation, tissues were thoroughly washed in buffer, infiltrated with $20 \%$ sucrose for $24 \mathrm{hr}$, rapidly frozen on a cryostat stage, and then cut into $25-\mu \mathrm{m}$-thick sections on a Leitz cryostat 1720 (Leitz, Wetzlar, Germany) and mounted onto chrome-alum-coated microscope slides. Tissue sections to be used for peptide ICC were taken directly to antiserum incubation, whereas for GABA ICC the best pretreatment was as follows (see Nässel and Eckström, 1997): the sections were incubated with 0.13 M sodium borohydride in $0.05 \mathrm{M}$ Tris $\mathrm{HCl}(15 \mathrm{~min})$ and then washed in buffer, or they were dehydrated in a graded ethanol series (50-99.5\%) and xylene and then rehydrated.

The antisera were applied on the sections for $48 \mathrm{hr}$ at $4^{\circ} \mathrm{C}$ in $0.01 \mathrm{M}$ PBS, $0.5 \%$ bovine serum albumin, and $0.25 \%$ Triton $\mathrm{X}-100$ at the following dilutions: anti-LomTK-I at 1:1000, anti-substance $P$ at 1:250, and anti-GABA at 1:2000. The primary antisera were detected by peroxidase-conjugated swine anti-rabbit (LomTK) (from Dako, Copenhagen, Denmark), by goat anti-rat (substance P) IgGs (Sigma, St. Louis, $\mathrm{MO}$ ), or by the ABC method (GABA) with peroxidase-tagged streptavidin using a Vectastain kit (Vector Laboratories, Burlingame, CA). As controls, both anti-LomTK (1:1000) and anti-substance P (1:500) were preabsorbed with LomTK-I peptide $\left(2 \times 10^{-5} \mathrm{M}\right)$ and applied to tissue sections as described above.

The sections were analyzed on either a Zeiss Axioplan II or a Zeiss Axiophot microscope equipped with interference contrast optics and epifluorescence. Images were either obtained as photographic slides (Kodak Ektachrome 100 or 400) or captured by an integrated chilled color CCD camera (Hamamatsu, Hamamatsu City, Japan). In both cases the images were edited in Adobe Photoshop 4.0 (photographic slides were digitized by means of a flatbed scanner, Umax PowerLook II; Umax Data Systems, Fremont, CA).

The physiological preparation. Crayfish of $7-10 \mathrm{~cm}$ in length and of both sexes were prepared as described by Glantz and Bartels (1994). The rostrum was removed, and the eyestalks were glued to the cephalic carapace with cyanoacrylate adhesive (Superglue). The lamina and receptor layer were exposed by excision of the dorsal cuticle of the eyestalk and the dorsal cornea. The animals were exsanguinated by perfusion with oxygenated crayfish saline at $10^{\circ} \mathrm{C}$ to prevent the formation of blood clots around the dissected area of tissue. Recordings were made with the eyecup in situ or with an isolated eyecup and brain preparation. The recording chamber consisted of a Plexiglas dish in which one wall contained a frosted glass plate to image the visual stimulus. The eye was $\sim 1.0 \mathrm{~cm}$ from the glass plate. After the dissection, the saline solution over the lamina was lowered to $\sim 0.5 \mathrm{~mm}$ above the tissue.

The visual stimulus. Visual stimuli were delivered by a $7.0 \mathrm{~mW} \mathrm{He}-\mathrm{Ne}$ laser beam directed to the eye by galvanometer-controlled mirrors. Intensity was controlled by a $6.0 \log$ unit neutral density wedge, and stimulus presentation was controlled by an electromagnetic shutter and pulse generator. The maximum intensity at the eye was $3.0 \mathrm{~mW} / \mathrm{mm}^{2}$. To minimize adaptation, stimuli were presented no more frequently than 1 stimulus $/ 5 \mathrm{sec}$. For prolonged repeated stimulus sequences, intensity was set to $<1.0 \%$ of the saturating intensity, stimulus duration was set to $0.2-0.5 \mathrm{sec}$, and the interstimulus interval was $8-10 \mathrm{sec}$.
Perfusion and ligand injection. As a TRP ligand, the cockroach peptide LemTRP-4, which differs from CabTRP-Ia by only one amino acid residue (a Met6 to Leu6 change) in a region likely to be unimportant for receptor binding and activation (Nässel, 1999), was used. During ligand injection the lamina and photoreceptors were perfused with crayfish saline at a rate of $0.1 \mathrm{ml} / \mathrm{sec}$. GABA at 0.1 or $1.0 \mathrm{~mm}$ and TRP at 1 or 10 $\mu \mathrm{M}$ were delivered to photoreceptor terminals in the lamina with pressure injection via separate capillaries with $10-15 \mu \mathrm{m}$ tips. Injection volumes of 0.01-1.0 $\mu \mathrm{l}$ were controlled by pulse pressure and duration. To minimize desensitization, GABA volumes were adjusted to elicit nonsaturating responses, and injection frequency was set to 1 injection/30 sec. TRP was either injected in nanoliter volumes or perfused over the lamina via continuous injection at $2-5 \mu \mathrm{l} / \mathrm{min}$.

Recording procedures and data analysis. Recording electrodes were filled with $3 \mathrm{M} \mathrm{K}^{+}$-acetate and selected for resistance $(\sim 100 \mathrm{M} \Omega)$ and speed (time constant $<0.1 \mathrm{msec}$ after capacity compensation). Photoreceptors were typically impaled in the distal retina in the relatively large soma-rhabdomere region. A few recordings were made in the axons close to the terminals.

Receptor signals were led to an Axoclamp-2B amplifier (Axon Instruments, Foster City, CA) that was switched between bridge mode, discontinuous current clamp, and discontinuous voltage clamp. In discontinuous modes, current injection and voltage measurements alternated during a $2.0 \mathrm{msec}$ duty cycle $(500 \mathrm{~Hz}$ sampling rate). Because the membrane time constant varies between $50 \mathrm{msec}$ (in the dark) and 20 msec (light adapted), the switching period is sufficiently fast to resolve all photoreceptor signals. The amplifier bandwidth was direct current to 30 $\mathrm{kHz}$. Input resistance measurements were performed in discontinuous current clamp with currents of -0.1 to $-0.3 \mathrm{nA}$, and the light-elicited responses were measured in either bridge mode or discontinuous voltageclamp mode.

Responses were digitized at $500 \mathrm{~Hz}$ via an analog-to-digital board and a 486 personal computer. To assess the reliability of the responses, visual stimuli and ligand applications were typically repeated five times, and the responses to each condition were averaged. Except where noted, data used in measurements and shown in the figures represent the averages of five or more responses that were low-pass filtered at $100 \mathrm{~Hz}$ after averaging. The SD of the averaged data rarely exceeded $\pm 10 \%$ of the mean response for visual stimuli and current pulses and was typically approximately $\pm 20 \%$ of the mean for TRP- and GABA-elicited responses.

\section{RESULTS}

\section{Immunocytochemistry}

The antiserum to the locust TRP, LomTK-I, and the monoclonal antibody to substance $\mathrm{P}$ are known to cross-react with the same neurons in insect and crustacean brains, probably by crossreacting with the cognate TRP (see Blitz et al., 1995; Johansson et al., 1999; Nässel, 1999). In crayfish brain both anti-LomTK and anti-substance P can be blocked by locust TRP (Johansson et al., 1999). We found that this is also the case in the optic lobes of the crayfish $P$. leniusculus. We thus refer to the substance P- and LomTK-immunoreactive neurons as TRP immunoreactive (TRP-IR). In the lamina the two antisera labeled numerous amacrine cells, the majority of which had cell bodies below the lamina synaptic layer (Fig. $1 A$ ). In each specimen, however, there were a small number of amacrines with displaced cell bodies. These are located distal to the lamina synaptic layer in the outer layer of monopolar cell bodies (see Fig. 1B). The amacrines form TRP-IR varicose processes that invade the lamina synaptic layer. At the distal and proximal borders of the neuropil the amacrine neurons form tangential processes with numerous varicosities along their length (Fig. $1 B, C$ ). Although the number of TRP-IR amacrines is far below that of synaptic units, cartridges of the lamina, their processes cover the entire projected retinal mosaic in the lamina. The amacrine processes are clearly within the domains of the photoreceptor terminals in the lamina.

In addition to the amacrines we also found TRP-IR neurons that interconnect the lamina and the medulla externa (Fig. 1A,D). 
Figure 1. Tachykinin-related peptide in crayfish ( $P$. leniusculus) optic lobe displayed by immunocytochemistry on cryostat sections (horizontal sections; peroxidase method). $A$, LomTK-immunoreactive (LTK-IR) neurons in the $L a$ and the $M e$. Note the cell bodies of $A m$ cells below the lamina. Some LTK-IR axons are seen connecting the lamina and the medulla (long arrow). In the medulla four main layers of LTK-IR processes can be resolved. The cell bodies of the lamina-medulla neurons are seen at the short arrow. $B$, Labeling with monoclonal antibody to substance $\mathrm{P}$. The $L a$ in higher magnification with cell bodies of $A m$ and $D-A m$ neurons is shown. Note the tangential processes running distally and proximally. $C$, Detail of substance P-immunoreactive $A m$ neurons in the lamina. Note the varicose processes in the synaptic neuropil (arrows). $D$, LomTK-IR neurons in the lamina. Ams are seen together with lamina-medulla neurons (e.g., at arrows). Together they form superimposed tangential processes. Those of the lamina-medulla neurons are less prominently immunolabeled. $A m$, Amacrine; $D-A m$, displaced-amacrine; $L a$, lamina; $M e$, medulla. Scale bars: $A, 0.1 \mathrm{~mm} ; B, 50 \mu \mathrm{m} ; C, D, 20 \mu \mathrm{m}$.
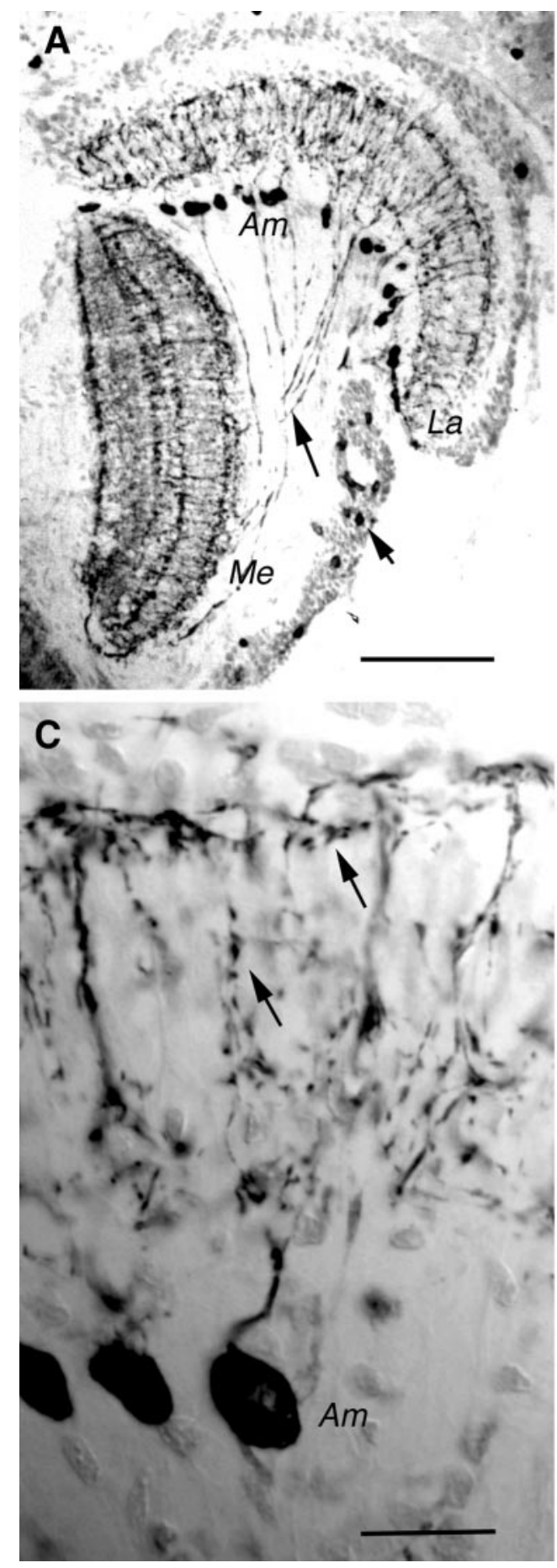
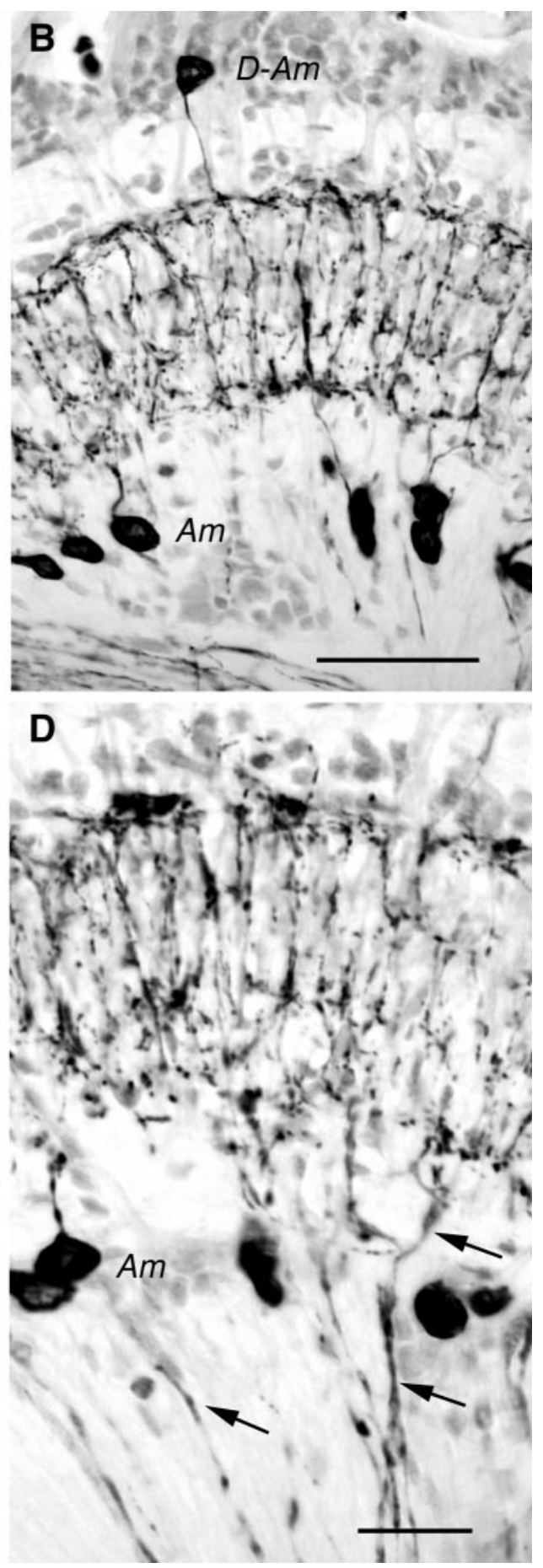

These neurons that have their cell bodies in the medulla cell body layer (in the outer optic chiasm; Fig. $1 A$ ) are present in a number substantially smaller than that of the cartridges and/or ommatidia. The arborizations within the lamina superimpose those of the amacrines (as shown in Fig. 1D), but because the immunolabeling is weaker in the lamina-medulla neurons a distinction can be made between the two types of neurons.

GABA immunoreactivity (GABA-IR) was seen in amacrines of the lamina and in neurons connecting the lamina and medulla externa (Fig. $2 A, B, D$ ). The amacrines have the same morphology as the TRP-IR ones (as shown in Fig. $2 B, C$ ). The laminamedulla-connecting neurons, however, are distinct from the TRP-
IR-interconnecting neurons (they form processes in a midlayer of the lamina, not seen after TRP immunocytochemistry; Fig. 2, compare $B-D)$. In addition, the GABA-IR neurons have cells bodies clustered anterior to the medulla (Fig. 2E). The GABA immunocytochemistry required specific fixation and pretreatment that precluded the possibility of double labeling with antiserum to substance P or LomTK. Thus we can only infer by indirect criteria that GABA- and TRP-immunoreactive material is colocalized in the amacrines. First, the number of amacrines displayed by each of the two antisera is approximately the same, and the morphology of the amacrines displayed by each of the two antisera is very similar (Fig. $2 B, C$ ). Second, the amacrines 

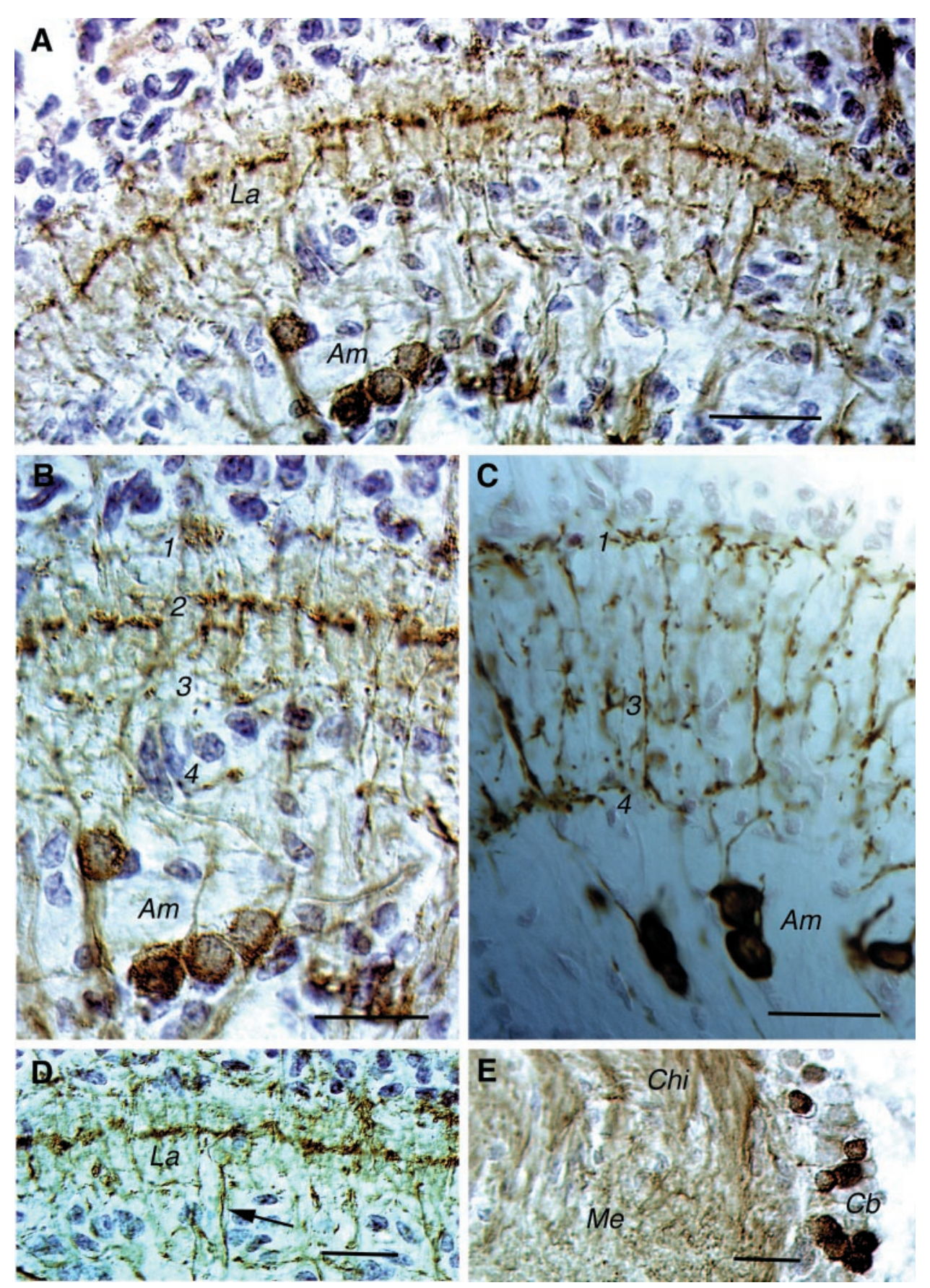

Figure 2. Cryostat sections of crayfish lamina (horizontal sections). $A$, GABAimmunoreactive neurons in the lamina of $P$. leniusculus (ABC method; counterstaining of nuclei with toluidine blue) are shown. Am neurons are labeled in addition to neurons connecting the $L a$ and the medulla (not clearly seen here; refer to $D)$. Note the immunolabeled processes in three layers of the lamina; the midlayer of tangential processes is most prominent. $B$, Detail of the lamina with cell bodies of GABA-immunoreactive Ams and processes in the synaptic neuropil in four layers (1-4) is shown. The processes in layer 2 are derived from the laminamedulla-connecting neurons. $C$, For comparison substance P-immunoreactive Ams (peroxidase method) are shown. Layers 1, 3 , and 4 are indicated; no processes are seen in layer 2. D, GABA-IR processes of the neurons connecting the $L a$ and the medulla form a tangential layer in the midregion of the lamina neuropil. One of the lamina-medulla-interconnecting axons is seen at the arrow. $E, C b$ of laminamedulla-interconnecting GABA-IR neurons reside adjacent to the $M e$ neuropil close to the Chi between the lamina and the medulla. $C b$, Cell bodies; $C h i$, chiasm. Scale bars: $A, D, E, 50 \mu \mathrm{m} ; B, C, 20 \mu \mathrm{m}$. have large nuclei, and counterstaining of the anti-GABA-labeled sections reveal that there are very few large nuclei below the lamina that are not in cell bodies that display GABA-IR (Fig. 2A,B).

\section{GABA hyperpolarizes photoreceptor terminals}

Previous studies (Wang-Bennett and Glantz, 1987; Glantz and Bartels, 1994) have shown that lateral inhibition in lamina monopolar cells is maximized by off-axis or broad-field illumination and appears to be expressed presynaptically. When photoreceptor responses are recorded in the soma there is no obvious sign of inhibition in the response to broad-field illumination (as shown in Fig. 3A). Recordings from photoreceptor axons, however, often reveal a hyperpolarizing afterpotential (implying inhibition) in the wake of the excitatory light response as shown in Figure $3 B$. At $\log _{10}$ intensity -3 , the afterpotential is approximately -1.0 $\mathrm{mV}$. It increases to $-3.0 \mathrm{mV}$ at intermediate intensities and is replaced with a depolarizing afterpotential at log intensity 0 .

Because a GABA-activated $\mathrm{Cl}^{-}$conductance appears to mediate presynaptic inhibition at crayfish neuromuscular junction (Takeuchi and Takeuchi, 1966) and in primary afferent terminals (Kennedy et al., 1980; Cattaert et al., 1994), it is possible that GABA is responsible for the light-elicited hyperpolarization of receptor terminals. The application of GABA to the lamina (where photoreceptor terminals are located) elicits a dosedependent hyperpolarization of the photoreceptor terminal (as shown in Fig. $4 A$ ). In axonal recordings the largest responses are 

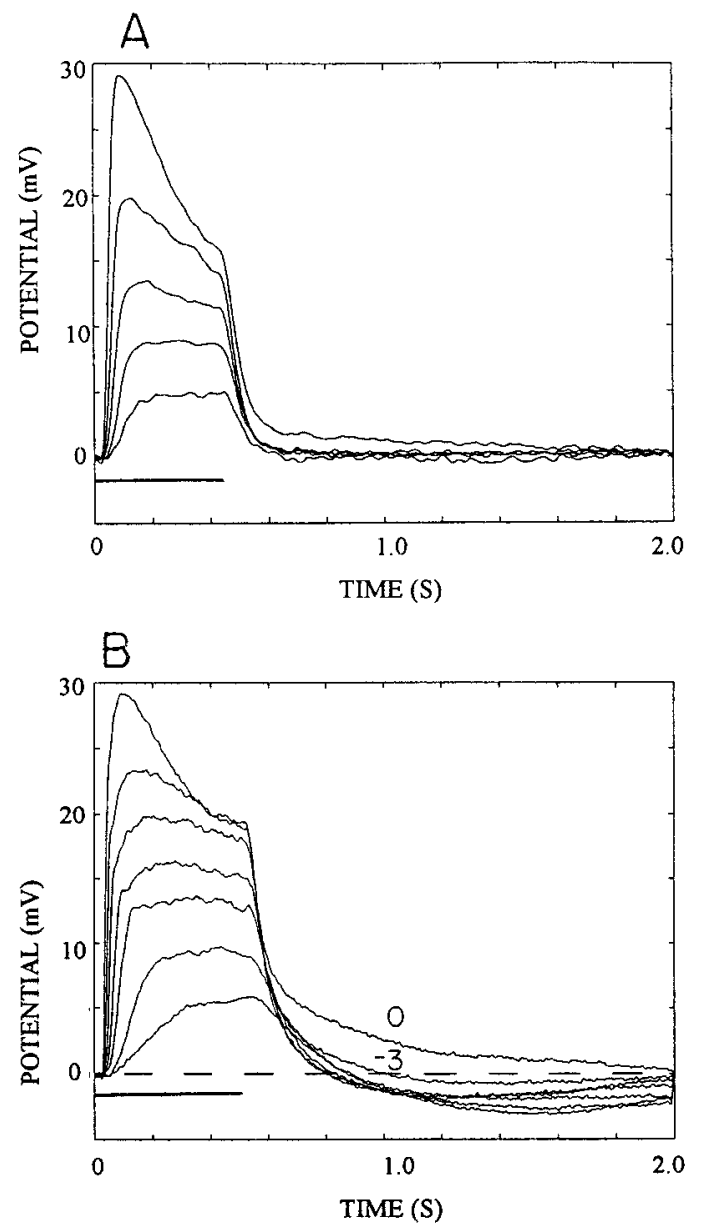

Figure 3. Comparison of the afterpotentials of soma and axonal photoreceptor responses elicited with broad-field $\left(20^{\circ}\right.$ solid angle) illumination. $A$, Soma responses to $0.5 \mathrm{sec}$ light flashes (horizontal bar at bottom left). Intensity was varied in $0.5 \log _{10}$ unit steps from -2.0 to 0 . Each trace is the average of five responses. $B$, Axonal recordings of responses to $0.55 \mathrm{sec}$ flashes with intensity varied from -3.0 to 0 in $0.5 \log _{10}$ steps. Each trace is the average of five responses. The broken line indicates the membrane resting potential that is taken as $0 \mathrm{mV}$. The afterpotentials at log intensity -3 and 0 are labeled. All other intensities produced similar afterpotentials.

-5 to $-10 \mathrm{mV}$ in amplitude. In soma recordings however the largest responses are approximately $-2 \mathrm{mV}$. The GABA-elicited response is relatively resistant to desensitization. An unusual feature of some arthropod chloride channels is that they are activated by acetylcholine (ACh) in addition to GABA (Zufall et al., 1988). In photoreceptor terminals, ACh elicited dosedependent hyperpolarizing responses as shown in Figure $4 B$. The sensitivity was similar to that of GABA with half-maximal responses at $\sim 10 \mu \mathrm{M}$ and saturation at $100 \mu \mathrm{M}$.

The GABA-elicited response is associated with an increase in membrane conductance that reduces the amplitude of both current-elicited (as shown in Fig. 5) and light-elicited (as shown in Fig. 6) membrane polarizations. A typical result from an axonal recording is shown in Figure $5 B$, in which the initial phase of the GABA-elicited response (shown in Fig. $5 A$ ) is associated with a reduction in the current-elicited polarization. This reduction indicates an increase in the receptor's input conductance from 38 to $54 \mathrm{nS}$. In most of our recordings the GABA-dependent reduction in the light response was modest (10-20\%) and consistent with a
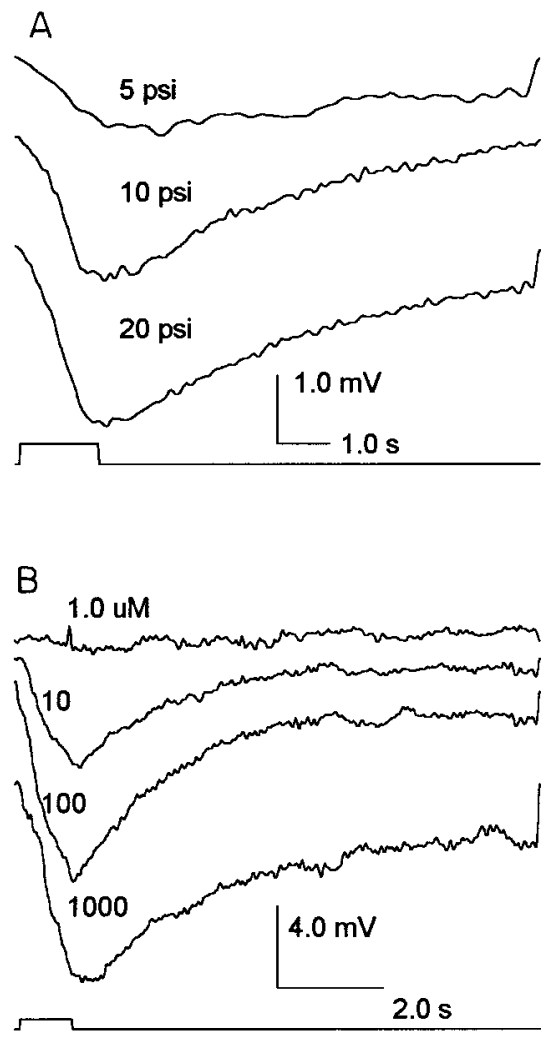

Figure 4. Receptor responses to GABA and acetylcholine injections in the lamina. A, Axonal recordings of receptor responses to $1.0 \mathrm{sec}$ pulses of $1.0 \mathrm{~mm}$ GABA (pipette concentration) at varied injection pressures are shown. Injection volume was linear with pressure, and 20 psi produced a $100 \mathrm{nl}$ volume. Each trace is the average of five responses. $B$, ACh was injected in $100 \mathrm{nl}$ volumes from a multibarrel pipette with pipette concentrations of 1.0, 10, 100, and $1000 \mu \mathrm{M}$ (as indicated above each trace). Each trace is the average of four responses.

small reduction in input resistance. The attenuation shown in Figure 6 is $\sim 30 \%$.

\section{TRP hyperpolarizes the receptor terminal}

Nanoliter volumes of 1.0 or $10 \mu \mathrm{M}$ TRP (LemTRP-4) elicited dose-dependent hyperpolarizations of $1-3 \mathrm{mV}$ in receptor terminals as shown in Figure 7. Note that the numbers above each trace in Figure 7 represent the gram-equivalent dose. The TRP concentration in the injection pipette was fixed $(10 \mu \mathrm{M})$, whereas the injected volume was varied with pressure. The actual concentrations are unknown, but they are $<10 \mu \mathrm{M}$ and presumably proportional to the injected dose. The responses typically peak at $0.5-1.0$ sec after the injection and decay to baseline after another 3-5 sec. Although TRP occasionally produced responses of up to $-5 \mathrm{mV}$, a range of $0.5-3.0 \mathrm{mV}$ was more common. TRP also produced modest reductions in receptor membrane input resistance as shown in Figure 8. Typical changes were 10-20\%, indicative of conductance increases of 5-10 nS.

A voltage-clamp analysis was undertaken in 14 cells to examine the action of TRP on voltage-dependent conductances. The receptor exhibits a leakage conductance and a delayed rectifier potassium conductance similar to those found in other arthropod receptors (Pepose and Lisman, 1978). The outward currents were insensitive to TRP (data not shown), but the leakage conductance exhibited modest increases with TRP perfusion consistent with the results in Figure 8. 

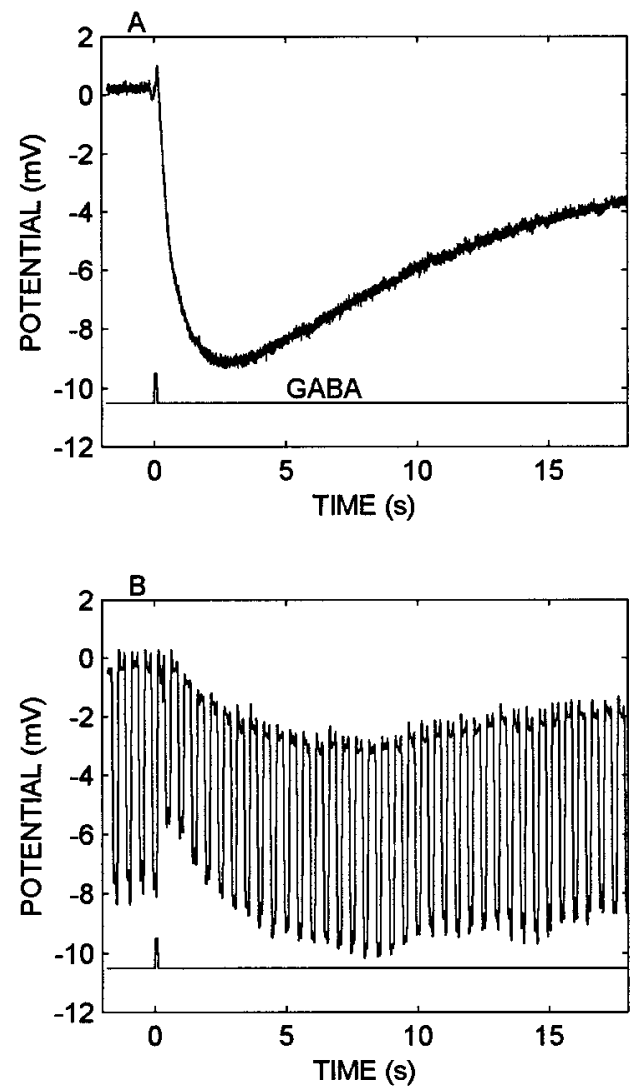

Figure 5. The GABA response is associated with an increase in membrane conductance. $A$, Axonal recording of GABA-elicited hyperpolarization (top trace). The GABA $(0.1 \mathrm{~mm})$ pulse (bottom trace) was at $20 \mathrm{psi}$ for $0.2 \mathrm{sec}$. The volume was $\sim 50 \mathrm{nl}$. $B$, Input resistance measurement during the GABA-elicited response. Stimulus conditions are described in $A$ but with a $0.2 \mathrm{sec},-0.3 \mathrm{nA}$ current pulse injected through the electrode at $2 \mathrm{~Hz}$ in the discontinuous current-clamp recording. The GABA injection increases the measured input conductance from 38 to $54 \mathrm{nS}$ during the early phase of the response, and the conductance declined to within $10 \%$ of the resting value as the hyperpolarization attained its maximum.

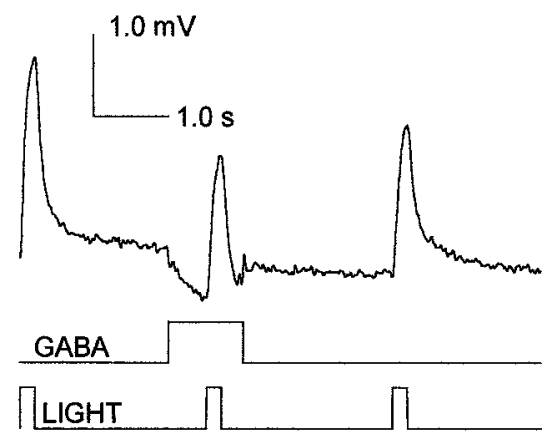

Figure 6. GABA attenuates the light response. Soma recording of receptor responses (top trace) to $0.2 \mathrm{sec}$ light flashes (bottom trace) at a $\log _{10}$ intensity of -3.5 and a stimulus repetition rate of $0.4 \mathrm{~Hz}$. Once every 30 sec a $0.1 \mathrm{~mm}$ GABA injection (1.0 sec pulse; $20 \mathrm{psi}$; middle trace) was timed to precede a light pulse by $0.5 \mathrm{sec}$. GABA reduced the light response from 2.7 to $1.8 \mathrm{mV}$, and the response recovered by $30 \%$ within $3.0 \mathrm{sec}$ after the start of the injection.

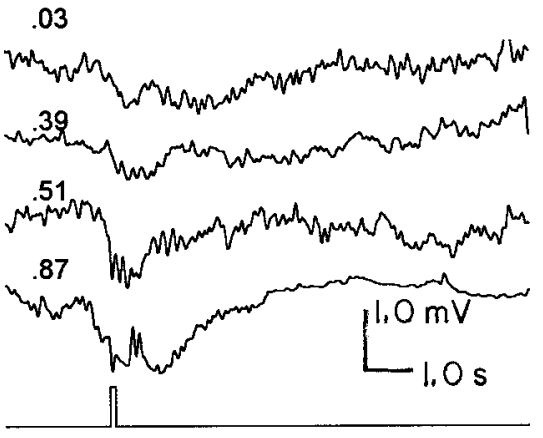

Figure 7. Photoreceptor responses recorded in the axon to pressure injections of TRP in the lamina. Stimulus duration (bottom trace) was 100 msec, and the pressure was varied to produce different injection volumes of a $10 \mu \mathrm{M}$ TRP solution in the pipette (top four traces). The numbers above each trace indicate the gram-equivalent injection dose in picomolar concentrations. Each trace is the average of three to five responses. Note that at $0.87 \mathrm{pM}$, the response appears to occur in two phases. The second phase (i.e., the large delayed hyperpolarization) was commonly observed with large injection volumes $(0.1 \mu \mathrm{l})$.

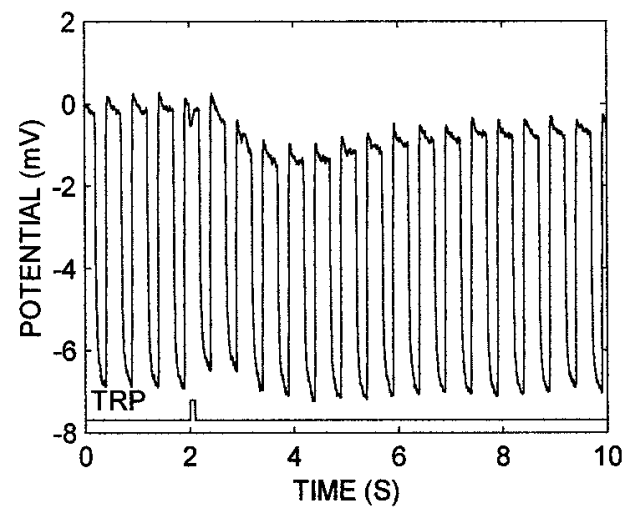

Figure 8. TRP injections produce a small increase in conductance in the photoreceptor terminal. Current pulses of $-0.3 \mathrm{nA}$ and $0.2 \mathrm{sec}$ duration and at 2 pulses/sec were injected into the receptor and synchronized to the timing of the TRP injection (bottom trace). After the TRP injection the voltage deflection declines from 6.7 to $5.7 \mathrm{mV}$, indicating a change in input conductance from 45 to $52 \mathrm{nS}$. The recordings were made in the axon in discontinuous current-clamp mode. The top trace is the average of four responses.

TRP also exhibits two additional actions consistent with a role in lateral inhibition or light adaptation: (1) a reduction in the photoreceptor's response to a flash of light that develops over several minutes and (2) potentiation of the action of GABA that also evolves on a time scale of minutes.

\section{TRP reduces the receptor potential}

If a light flash is presented during or immediately after a single TRP pulse, the receptor potential is unaffected. Significant modulation was observed however over a longer time scale and with continuous perfusion.

Figure 9 shows light responses elicited by flashes of constant intensity in control conditions (Fig. $9 A, 0$ min perfusion), during a 5 min perfusion of the lamina with $1.0 \mu \mathrm{M}$ TRP (Fig. $9 A$ ), and after a wash with saline (Fig. $9 B$ ). In this cell the TRP reduced the light response by $40 \%$ in $5 \mathrm{~min}$. Similar results were obtained in 19 of 20 cells tested, and these cells exhibited a $37.9 \pm 4.3 \%( \pm$ $\mathrm{SE})$ response attenuation in 3-5 min that was associated with a $70 \%$ reduction in visual sensitivity. Similar results were obtained with 1 and $10 \mu \mathrm{M}$ TRP. 


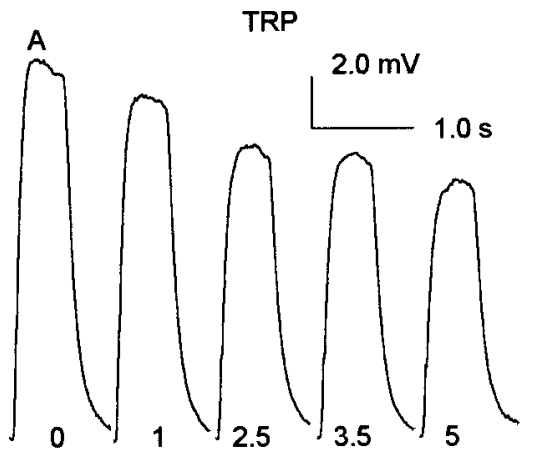

B

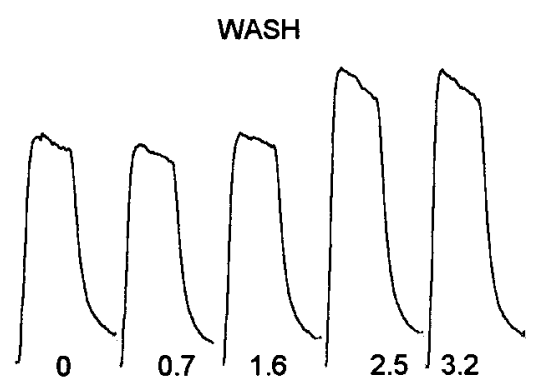

Figure 9. TRP perfusion produces a reversible reduction of the photoreceptor's light response. $A$, Light flashes ( $0.55 \mathrm{sec}$ duration; $\log _{10}$ intensity $=-2.0$ ) were presented continuously at one flash $/ 8 \mathrm{sec}$ until a stable adaptation level was achieved. The sample labeled " 0 " is the average of 10 responses just before the onset of TRP perfusion $(1.0 \mu \mathrm{l} / \mathrm{min} ; 1.0 \mu \mathrm{M})$. The remaining four responses show the decline in the visual response between 1.0 and $5.0 \mathrm{~min}$ after the onset of perfusion. Each response is labeled with the time from perfusion onset to the beginning of the sample period. At the end of $5 \mathrm{~min}$, the TRP perfusion was terminated, and after a $1.0 \mathrm{~min}$ hiatus, a saline wash was commenced. $B$, The 0 response is the average of the first five responses during the wash. The remaining records are averages of five successive responses beginning at the times indicated in minutes at the bottom of each trace.

Because TRP reduces the receptor potential to a much greater degree than the input resistance, it is possible that TRP has actions in the visual transduction pathway or on a voltage-gated inward current associated with the receptor potential. Figure 10, $A$ and $B$, compares receptor potentials elicited at four flash intensities in control and during TRP perfusion. TRP reduced the receptor potential by $\sim 50 \%$ except at the highest intensity at which the reduction is $12 \%$. Figure $10, C$ and $D$, shows the light-activated currents (measured at $-60 \mathrm{mV}$, the membrane resting potential) at the same intensities and under the same conditions. TRP reduced the currents at all intensities by $\sim 55 \%$. The attenuations of the voltage and current responses will not be precisely proportional because of different effects of the input conductance, reversal potential, and voltage-dependent outward current on the two measurements. Furthermore, the measurements in Figure 10 do not distinguish between TRP actions on the photochemical cascade and actions on the light-activated ion channels. In four comparable experiments the results indicated that most or all of the TRP-dependent reduction in receptor potential could be caused by a corresponding reduction in the light-activated current.

Because the TRP actions on photocurrent were observed with the photoreceptors clamped at the membrane resting potential (as shown in Fig. 10), voltage-gated currents do not contribute to the TRP-dependent attenuations of the light-elicited current. It is possible however that TRP might modulate a voltage-gated inward current that contributes to the receptor potential. Although we have found no convincing evidence of a voltage-dependent inward current (even with outward currents partially blocked with tetraethylammonium), we are not prepared to say that they are absent and that they could not contribute to the TRP action on the receptor potential.

\section{TRP potentiates the response to GABA}

TRP perfusion produces a reversible increase in the response to GABA, as shown in Figure 11. In soma recordings the response to GABA increased in six of seven cells tested from $-0.52 \pm 0.13$ $\mathrm{mV}$ ( $\pm \mathrm{SE}$ ) to $-1.26 \pm 0.22 \mathrm{mV}$ ( $\pm \mathrm{SE})$. The enhancement evolved over $2-5 \mathrm{~min}$. The TRP effect was sufficiently robust that the TRP-dependent potentiation could be repeated in the same cell after a wash to restore normal GABA responsiveness (Fig. 11 , third, fourth traces). A 50\% recovery typically required $\sim 5$ min. The GABA-elicited responses were not altered by single TRP injections whether the two were simultaneous or with GABA delayed by up to $10 \mathrm{sec}$.

\section{DISCUSSION}

Our principal findings are that the amacrine neurons of the crayfish lamina ganglionaris contain TRP and GABA. The neurites of the amacrine neurons arborize in the lamina layers that contain photoreceptor terminals. Both GABA and TRP produce actions consistent with presynaptic inhibition of the primary visual synapse. These actions include relatively fast, dosedependent hyperpolarizations of the photoreceptor terminal associated with small increases in membrane conductance. Furthermore, TRP produces a slow reduction of the light-elicited photoreceptor current and reversibly potentiates the action of GABA. This is the first evidence of peptidergic modulation of sensory cells in arthropods. The results support inhibitory actions of TRP in contrast with the commonly reported excitatory action of vertebrate tachykinins (see Otsuka and Yoshioka, 1993).

\section{Colocalization of TRP and GABA}

The present results indicate that amacrines of the crayfish lamina ganglionaris [first described by Strausfeld and Nässel (1981)] contain TRP and probably colocalized GABA. It was shown previously that antisera to FMRFamide and to the octadecapeptide pigment-dispersing hormone were colocalized in neurons likely to be amacrines of the crayfish lamina ganglionaris (Mangerich et al., 1988). Thus it is possible that the same amacrines colocalize members of three peptide families and GABA. Because the immunocytochemistry protocols for neuropeptides and neuroactive amino acids are not compatible, we did not obtain clear double-label evidence of the TRP and GABA colocalization. Only indirect evidence suggests this colocalization; the numbers of TRP- and GABA-immunoreactive amacrines are approximately the same, and the morphology and distributions of the neurons are very similar. It is also known that GABA and TRPs are colocalized in neurons of the insect brain (see Nässel, 1999) and that in the vertebrate retina GABA and substance $P$ have been found to be colocalized in amacrine and ganglion cells (Pourcho and Goebel, 1988; Caruso et al., 1990; Cuenca and Kolb, 1998). Because two additional types of lamina neurons (connecting to the medulla externa) contain TRP and GABA, 

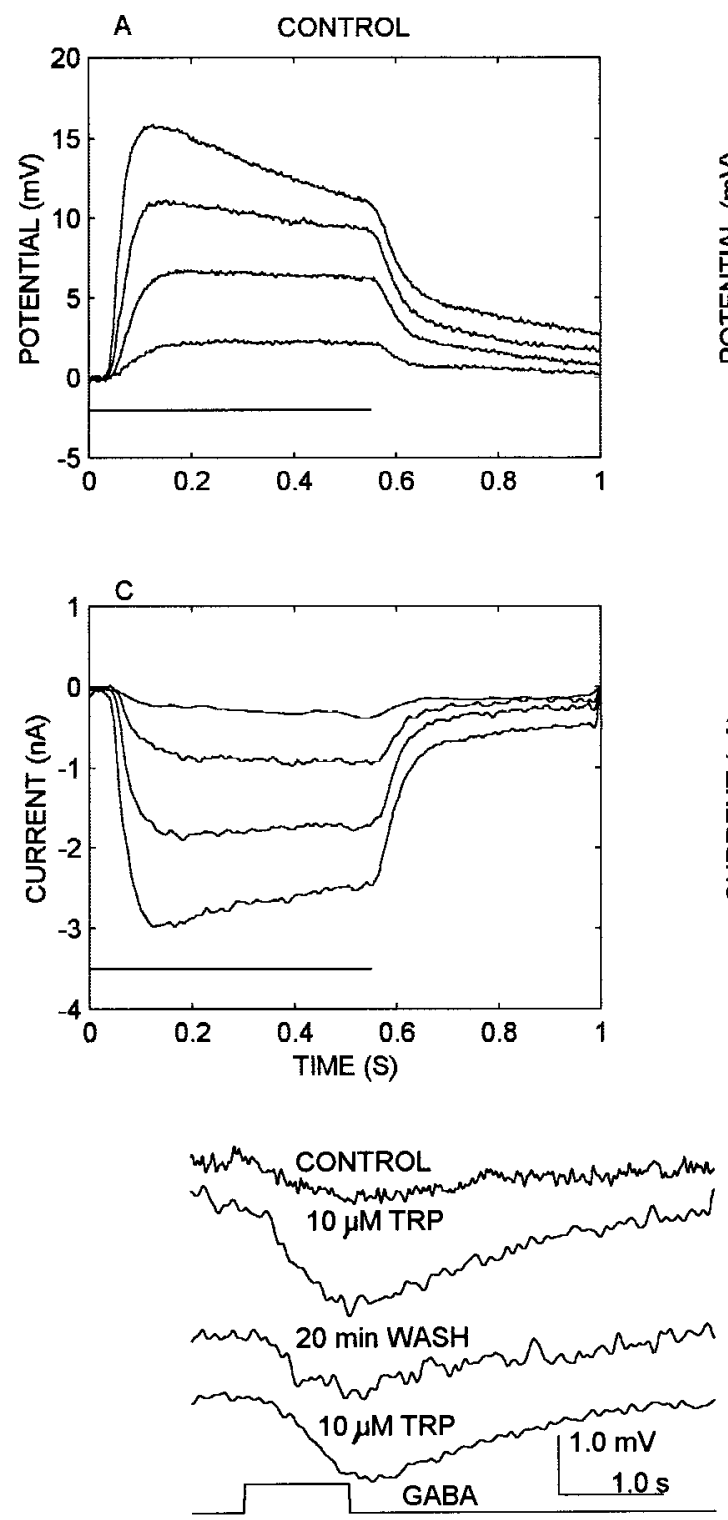

Figure 11. TRP reversibly increases the receptor response to GABA. The top four traces show averaged responses to $0.1 \mathrm{~mm}$ GABA injections (20 psi for $1.0 \mathrm{sec}$; bottom trace) in control conditions (top trace), during perfusion with $10 \mu \mathrm{M}$ TRP (second trace from the top), at the end of a 20 min saline wash (third trace from the top), and during a second perfusion with TRP (fourth trace from the top). Each trace is the average of five responses.

respectively, it is possible that the observed actions of TRPs and GABA may not depend on the amacrines.

\section{Inhibitory actions of GABA and TRP}

The interpretation of the physiological data is based on a working hypothesis that lamina amacrine neurons are excited (directly or indirectly) by photoreceptor cells and that the amacrine neurons provide inhibitory feedback to the photoreceptor terminals (Glantz and Bartels, 1994). The hyperpolarization of receptor terminals by broad-field illumination and by GABA and TRP is consistent with this hypothesis. Furthermore, GABA is associated with presynaptic inhibition and increased $\mathrm{Cl}^{-}$conductance at both peripheral and central crustacean synapses (Kennedy et al., 1980; Glantz et al., 1985; Finger and Martin, 1989; Cattaert et al., 1994). Because the actions of ACh are similar to those of
Figure 10. Receptor potentials and light-elicited currents are diminished by TRP. $A$, Receptor potential responses to four flash intensities from $\log _{10}-4.0$ to -2.5 in $0.5 \log$ unit steps in control conditions. The flash duration (horizontal bar at bottom left) was 0.55 sec. $B$, Receptor potential responses to the flash intensities described in $A$ but during perfusion of the lamina with $1.0 \mu \mathrm{M}$ TRP at 5.0 $\mu \mathrm{l} / \mathrm{min}$. $C$, Receptor currents elicited by the same stimuli shown in $A$ and measured in voltage clamp at the membrane resting potential $(-60 \mathrm{mV})$ in control conditions. $D$, Receptor currents as described in $C$ but during TRP perfusion. Each trace is the average of three to five responses.

GABA, it is possible that the photoreceptor's GABA receptor is similar to the nonjunctional receptors of crustacean muscle $(\mathrm{Zu}-$ fall et al., 1988). In the lamina of flies (Hardie, 1987), GABA depolarizes the lamina monopolar cells (LMCs) and diminishes the cell's input conductance. These actions mimic the effects of off-axis illumination in both flies (Dubs, 1982; Laughlin and Osorio, 1989) and crayfish (Wang-Bennett and Glantz, 1987). In preliminary studies of crayfish LMCs, GABA reduced the LMC light response. The size of the GABA-elicited response in photoreceptor terminals implies a capacity for strong inhibition. In crayfish (Glantz, 1991) and other arthropods, contrast stimuli elicit receptor potentials of a few millivolts, comparable with the magnitude of the GABA-elicited response.

The physiological actions of TRP are also consistent with both short-term and long-term roles in presynaptic inhibition. The TRP-elicited hyperpolarization and modest increase in terminal input conductance are similar to the actions of GABA and should reduce transmitter release by the photoreceptor. Previous studies have shown that substance $\mathrm{P}$ can increase the leakage conductance in sympathetic neurons (Jones and Adams, 1987) and increase a Cl${ }^{-}$conductance (Janssen and Sims, 1994) in smooth muscle cells. Either finding could be the basis of the observations reported here.

The reduction of receptor potential by TRP is opposite to the effects of substance $\mathrm{P}$ on the Limulus photoresponse (Mancillas and Selverston, 1984). Any one of a number of differences between the studies might account for the different results. These include species differences or differences in the ligands (substance P vs LemTRP-4), the site of application (retinula perfusion in Limulus vs lamina injection in crayfish), or the effective concentration ranges (1.0-100 $\mathrm{nm}$ in Limulus vs $1-10 \mu \mathrm{M}$ in crayfish). Another important distinction is that substance $\mathrm{P}$ actions in 
Limulus appear to reflect principally the migration of shielding pigments and changes in rhabdome structure that in turn alter the quantum catch. A comparable system in crayfish (Arechiga et al., 1990) responds to serotonin to increase visual sensitivity. The response has a latency of $20 \mathrm{~min}$ and a time to peak of $40 \mathrm{~min}$. This should be compared with the 3-5 min time course of sensitivity changes after TRP injection.

Thus we interpret the reduction of the receptor potential by TRP as principally attributable to an attenuation of the lightelicited current and TRP action on visual transduction. This influence could be mediated by a TRP-dependent rise in intracellular $\mathrm{Ca}^{2+}$ (Li et al., 1991; Nakanishi, 1991). Intracellular $\mathrm{Ca}^{2+}$ is known to reduce arthropod light sensitivity during light adaptation (Lisman and Brown, 1972), and it is possible that TRP shares a common pathway. In mammals, tachykinin receptors are coupled to G-proteins and in many cases activate the phospholipase C pathway. This pathway involves inositol phospholipid hydrolysis and production of inositol triphosphate and diacylglycerol that in turn induce a rise in intracellular $\mathrm{Ca}^{2+}$ and the activation of protein kinase $\mathrm{C}$, respectively (Guard and Watson, 1991; Otsuka and Yoshioka, 1993). When cloned TRP receptors from Drosophila were heterologously expressed, ligand exposure activated the phospholipase $\mathrm{C}$ pathway and a $\mathrm{Ca}^{2+}$-dependent $\mathrm{Cl}^{-}$conductance ( $\mathrm{Li}$ et al., 1991; Monnier et al., 1992).

The enhancement of the photoreceptor's GABA-elicited response by TRP suggests a novel action of TRP on GABA receptors, but other possibilities based on indirect TRP actions (Kouznetsova and Nistri, 1998; Maubach et al., 1998) have not been eliminated. There are a few reports that suggest TRP modulation of ligand-gated conductances (Otsuka and Yoshioka, 1993; Yamada and Akasu, 1996; Parker and Grillner, 1998). For example, in avian sympathetic ganglia and bovine chromaffin cells, substance $\mathrm{P}$ increases the rate of desensitization of the nicotinic acetylcholine receptor. This action is probably mediated by the phospholipase $\mathrm{C}$ pathway and the activation of protein kinase C (Clapham and Neher, 1984; Simmons et al., 1990).

Morphological evidence suggests that TRP and GABA might have synergistic actions in some systems. TRP and GABA are colocalized in locust brain neurons (Vitzthum and Homberg, 1998), in cat spinal dorsal horn neurons (Ma and Ribeiro-daSilva, 1995), in motor neurons of guinea pig small intestine (Williamson et al., 1996), in primate and rat retinal amacrine cells (Caruso et al., 1990; Casini et al., 1997; Cuenca and Kolb, 1998), and in primate frontal cortex (Jakab et al., 1997). Our evidence supporting synergistic GABA-TRP inhibitory actions is generally consistent with observations of inhibitory influences of substance $\mathrm{P}$ in mammalian brain (Kow and Pfaff, 1988; Margeta-Mitrovic et al., 1997), in peripheral ganglia (Jones and Adams, 1987; Gilbert et al., 1998), in smooth muscle (Sun et al., 1993; Janssen and Sims, 1994), and in lobster olfactory neurons (Schmidt and Ache, 1994). In this context it is notable that in addition to TRP, crayfish amacrine neurons contain a FMRFamide-like peptide (Mangerich et al., 1988). In the mollusc Aplysia FMRFamide has potent presynaptic inhibitory effects (Belardetti et al., 1987; Sweatt et al., 1989; Dreijer et al., 1995; Klein, 1995) based on an enhancement of $\mathrm{K} \mathrm{K}^{+}$current and a reduction of a $\mathrm{Ca}^{2+}$ current. On the contrary side, much evidence attests to excitatory effects of TRPs in both vertebrates (Maggio, 1988; Nakanishi, 1991) and arthropods (Blitz et al., 1995; Christie et al., 1997; Lundquist and Nässel, 1997), and there is also evidence that substance P antagonizes GABA action (Yamada and Akasu, 1996).

The results prompt the question of why two or perhaps three agents (including FMRFamide) contribute to inhibition of photoreceptor terminals. Although GABA and TRP have some similar actions, the stronger effects of TRP are distinct from the actions of GABA and are expressed over a longer time scale. As noted previously, lateral inhibition is the basis of contrast enhancement and contributes to neural gain control during visual adaptation. Contrast enhancement functions operate over short (millisecond to second) time scales similar to the time course of GABA and the fast TRP actions. Some aspects of light adaptation evolve slowly, and the time course is more compatible with the slower TRP actions. A related possibility is that the different substances may be released by amacrine cells under quantitatively different levels of excitation (Marder et al., 1995). Thus GABA release might be modulated by normal contrast stimuli, and TRP may be released by more substantial (e.g., order of magnitude) increases in mean intensity. There is extensive evidence that neuromodulatory substances may increase photoreceptor sensitivity in the context of dark adaptation and/or circadian rhythms. In crayfish (Arechiga et al., 1990), flies (Hevers and Hardie, 1995), and locust (Cuttle et al., 1995), serotonin increases the receptor potential by modulating a $\mathrm{K}^{+}$conductance (in insects). In Limulus lateral eye, substance $\mathrm{P}$ and octopamine increase retinal sensitivity. Substance $\mathrm{P}$ produces alterations in the dioptric apparatus (Mancillas and Selverston, 1984). Octopamine also influences ommatidial structure (Kass and Barlow, 1984) and appears to modulate voltage-gated currents activated during the light response (Kass et al., 1988; Renninger et al., 1989). The modulation is expressed with a circadian rhythm.

We do not know whether lamina amacrine neurons synapse on photoreceptor terminals or whether GABA or TRP release is light dependent. The presence of GABA and TRP in amacrine neurons and the actions of these ligands on photoreceptor terminals in the lamina are consistent with their roles in lateral or feedback inhibition of the primary visual synapse. The pronounced and prolonged effects of TRP on both the visual response and the actions of GABA indicate that the transduction pathway that subserves TRP action has broad modulatory control over photoreceptor function.

\section{REFERENCES}

Arechiga H, Banuelos E, Frixione E, Picones A, Rodriguez-Sosa L (1990) Modulation of crayfish retinal sensitivity by 5-hydroxytryptamine. J Exp Biol 150:123-143.

Attwell D, Werblin FS, Wilson M, Wu S (1983) A sign-reversing pathway from rods to double and single cones in the retina of the tiger salamander. J Physiol (Lond) 336:313-333.

Belardetti ER, Kandel ER, Siegelbaum SA (1987) Neuronal inhibition by the peptide FMRFamide involves opening of $\mathrm{S} \mathrm{K}^{+}$channels. Nature 325:153-156.

Blitz DM, Christie AE, Marder E, Nusbaum MP (1995) Distribution and effects of tachykinin-like peptides in the stomatogastric nervous system of the crab, Cancer borealis. J Comp Neurol 354:282-294.

Caruso DM, Owczarzak MT, Puorcho RG (1990) Colocalization of substance $\mathrm{P}$ and GABA in retinal ganglion cells: a computer-assisted visualization. Vis Neurosci 5:389-394.

Casini G, Rickman DW, Sternini C, Brecha NC (1997) Neurokinin 1 receptor expression in the rat retina. J Comp Neurol 389:496-507.

Cattaert D, el Manira A, Clarac F (1994) Chloride conductance produces both presynaptic inhibition and antidromic spikes in primary afferents. Brain Res 666:109-112.

Christie AE, Lundquist CT, Nässel DR, Nusbaum MP (1997) Tachykinin related peptides in the nervous system of the crab, Cancer borealis. J Exp Biol 200:2279-2294.

Clapham DE, Neher E (1984) Substance P reduces acetylcholineinduced currents in isolated bovine chromaffin cells. J Physiol (Lond) 347:255-277. 
Cuello AC, Galfre G, Milstein C (1979) Detection of substance P in the central nervous system by a monoclonal antibody. Proc Natl Acad Sci USA 76:3532-3536.

Cuenca N, Kolb H (1998) Circuitry and role of substance P-immunoreactive neurons in the primate retina. J Comp Neurol 393:439-456.

Cuttle MF, Hevers W, Laughlin SB, Hardie RC (1995) Diurnal modulation of photoreceptor potassium conductance in the locust. J Comp Physiol [A] 176:307-316.

Dreijer AMC, Verheule S, Kits KS (1995) Inhibition of slowly inactivating high-voltage-activated calcium current by the neuropeptide FMRFa in molluscan neuroendocrine cells. Invert Neurosci 1:75-86.

Dubs A (1982) The spatial integration of signals in the retina and lamina of the fly compound eye under different conditions of luminance. J Comp Physiol [A] 146:321-343.

Finger W, Martin C (1989) Presynaptic effect of gamma-aminobutyric acid on the inhibitory nerve and nerve terminals in the crayfish neuromuscular junction. Neurosci Lett 97:129-134.

Fingerman M, Hanumante MM, Kulkarni GK, Ikeda R, Vacca L (1985) Localization of substance P-like, leucine-enkephalin-like, methionineenkephalin-like and FMRFamide-like immunoreactivity in the eyestalk of the fiddler crab, Uca pugilator. Cell Tissue Res 241:473-477.

Füller H, Eckert M, Blechschmidt K (1989) Distribution of GABA-like immunoreactive neurons in the optic lobes of Periplaneta americana. Cell Tissue Res 255:225-233.

Gilbert R, Ryan JS, Horackova M, Smith FM, Kelly ME (1998) The actions of substance $\mathrm{P}$ on membrane potential and ionic currents in guinea pig stellate ganglion neurons. Am J Physiol 274:C892-C903.

Glantz RM (1991) Motion detection and adaptation in crayfish photoreceptors: a spatiotemporal analysis of linear movement sensitivity. J Gen Physiol 97:777-797.

Glantz RM, Bartels A (1994) The spatiotemporal transfer function of crayfish lamina monopolar neurons. J Neurophysiol 71:2168-2182.

Glantz RM, Wang-Bennett L, Waldrop B (1985) Presynaptic inhibition in the crayfish brain. J Comp Physiol [A] 156:477-487.

Goldberg D, Nusbaum MP, Marder E (1988) Substance P-like immunoreactivity in the stomatogastric ganglion of the crab Cancer borealis and the lobsters Panulirus interruptus and Homarus americanus. Cell Tissue Res 252:515-522.

Guard S, Watson SP (1991) Tachykinin receptor types: classification and membrane signalling mechanisms. Neurochem Int 18:149-165.

Hamori J, Horridge GA (1966) The lobster optic lamina. II. Types of synapses. J Cell Sci 1:257-270.

Hardie RC (1987) Is histamine a neurotransmitter in insect photoreceptors? J Comp Physiol [A] 161:201-213.

Hevers N, Hardie RC (1995) Serotonin modulates the voltage dependence of delayed rectifier and shaker potassium channels in Drosophila photoreceptors. Neuron 14:845-856.

Jakab RL, Goldman-Rakic P, Leranth C (1997) Dual role of substance P/GABA axons in cortical neurotransmission: synaptic triads on pyramidal cell spines and basket-like innervation of layer II-III calbindin interneurons in primate prefrontal cortex. Cereb Cortex 7:359-373.

Janssen LJ, Sims SM (1994) Substance P activates $\mathrm{Cl}^{-}$and $\mathrm{K}^{+}$conductances in guinea-pig tracheal smooth muscle cells. Can J Physiol Pharmacol 72:705-710.

Johansson KUI, Lundquist CT, Hallberg E, Nässel DR (1999) Tachykinin-related neuropeptide in the crayfish olfactory midbrain. Cell Tissue Res 296:405-415.

Jones SW, Adams PR (1987) The M-current and other potassium currents of vertebrate neurons. In: Neuromodulation (Kaczmarek LC, Levitan IB, eds), pp 159-186. Oxford: Oxford UP.

Karten HJ, Brecha N (1980) Localization of substance P immunoreactivity in amacrine cells of the retina. Nature 283:87-88.

Kass L, Barlow RB (1984) Efferent neurotransmission of circadian rhythms in Limulus lateral eye. I. Octopamine-induced changes in retinal sensitivity. J Neurosci 4:908-917.

Kass L, Pelletier JL, Renninger GH, Barlow Jr RB (1988) Efferent neurotransmission of circadian rhythms in Limulus lateral eye. II. Intracellular recordings in vitro. J Comp Physiol [A] 164:95-105.

Kennedy D, McVittie J, Calabrese R, Fricke RA, Craelius W, Chiapella P (1980) Inhibition of mechanosensory interneurons in the crayfish. I. Presynaptic inhibition from giant fibers. J Neurophysiol 43:1495-1509.

Klein M (1995) Modulation of ion currents and regulation of transmitter release in short-term synaptic plasticity: the rise and fall of the action potential. Invert Neurosci 1:15-24.
Kouznetsova M, Nistri A (1998) Modulation by substance P of synaptic transmission in the mouse hippocampal slice. Eur $\mathrm{J}$ Neurosci 10:3076-3084.

Kow L-M, Pfaff DW (1988) Neuromodulatory actions of peptides. Annu Rev Pharmacol Toxicol 28:163-188.

Laughlin SB, Osorio D (1989) Mechanisms for neural signal enhancement in blowfly compound eye. J Exp Biol 144:113-146.

Li XJ, Wolfgang W, Wu YN, North RA, Forte M (1991) Cloning and heterologous expression and developmental regulation of a Drosophila receptor for tachykinin-like peptides. EMBO J 10:3221-3229.

Lisman JE, Brown JE (1972) The effects of intracellular iontophoretic injection of calcium and sodium ions on the light response of Limulus ventral photoreceptors. J Gen Physiol 59:701-719.

Lundquist CT, Nässel DR (1997) Peptidergic activation of locust dorsal unpaired median neurons: depolarization induced by locustatachykinins may be mediated by cyclic AMP. J Neurobiol 33:297-315.

Lundquist CT, Clottens FL, Holman GM, Riehm JP, Bonkale W, Nässel DR (1994) Locustatachykinin immunoreactivity in the blowfly central nervous system and intestine. J Comp Neurol 341:225-240.

Ma W, Ribeiro-da-Silva A (1995) Substance P- and GABA-like immunoreactivities are co-localized in axonal varicosities in the superficial laminae of cat but not rat spinal cord. Brain Res 692:99-110.

Maggio JE (1988) Tachykinins. Annu Rev Neurosci 11:13-28.

Mancillas JR, Selverston AI (1984) Neuropeptide modulation of photosensitivity. II. Physiological and anatomical effects of substance P on the lateral eye of Limulus. J Neurosci 4:847-859.

Mancillas JR, McGinty JF, Selverston AI, Karten H, Bloom FE (1981) Immunocytochemical localization of enkephalin and substance $\mathrm{P}$ in retina and eyestalk neurones of lobster. Nature 293:576-578.

Mangerich S, Keller R, Dircksen H, Rao KR, Riehm JP (1988) Immunocytochemical localization of pigment-dispersing hormone and its coexistence with FMRFamide immunoreactive material in the eyestalks of the decapod crustaceans Carcinus maenas and Orconectes limosus. Cell Tissue Res 250:365-375.

Marder E, Christie AE, Kilman VL (1995) Functional organization of cotransmission systems: lessons from small nervous systems. Invert Neurosci 1:105-112.

Margeta-Mitrovic M, Grigg JJ, Koyano K, Nakajima Y, Nakajima S (1997) Neurotensin and substance P inhibit low- and high-voltageactivated $\mathrm{Ca} 2+$ channels in cultured newborn rat nucleus basalis neurons. J Neurophysiol 78:1341-1352.

Maubach KA, Cody C, Jones RS (1998) Tachykinins may modify spontaneous epileptiform activity in the rat entorhinal cortex in vitro by activating GABAergic inhibition. Neuroscience 83:1047-1062.

Monnier D, Colas JF, Rosay P, Hen R, Borrelli E, Maroteaux L (1992) NKD, a developmentally regulated tachykinin receptor in Drosophila. J Biol Chem 267:1298-1302.

Nakanishi S (1991) Mammalian tachykinin receptors. Annu Rev Neurosci 14:123-136.

Nässel DR (1993) Insect myotropic peptides: differential distribution of locustatachykinin- and leucokinin-like immunoreactive neurons in the locust brain. Cell Tissue Res 274:27-40.

Nässel DR (1999) Tachykinin-related peptides in invertebrates. A review. Peptides 20:141-158.

Nässel DR, Eckström P (1997) Detection of neuropeptides by immunocytochemistry. In: Methods in molecular biology, Vol 7, Neurotransmitter methods (Rayne RC, ed), pp 71-101. Totowa, NJ: Humana.

Nieto J, Veelaert D, Derua R, Waelkens E, Cerstiaens A, Coast G, Devreese B, Van Beeumen J, Calderon J, De Loof A, Schoofs L (1998) Identification of one tachykinin- and two kinin-related peptides in the brain of the white shrimp, Penaeus vannamei. Biochem Biophys Res Commun 248:406-411.

Otsuka M, Yoshioka K (1993) Neurotransmitter functions of mammalian tachykinins. Physiol Rev 73:229-308.

Parker D, Grillner S (1998) Cellular and synaptic modulation underlying substance P-mediated plasticity of the lamprey locomotor network. J Neurosci 18:8095-8110.

Pepose JS, Lisman JE (1978) Voltage-sensitive potassium channels in Limulus ventral photoreceptors. J Gen Physiol 71:101-120.

Pourcho RG, Goebel DJ (1988) Colocalization of substance P and GABA in amacrine cells of the cat retina. Brain Res 447:164-168.

Renninger GH, Schimmel R, Farrell CA (1989) Octopamine modulates 
photoreceptor function in the Limulus lateral eye. Vis Neurosci 3:83-94.

Sandeman RE, Sandeman DC, Watson A (1990) Substance P antibody reveals homologous neurons with axon terminals among somata in the crayfish and crab brain. J Comp Neurol 294:569-582.

Schmidt M, Ache BW (1994) Descending neurons with dopamine-like or with substance P/FMRFamide-like immunoreactivity target somata of olfactory neurons in the brain of the spiny lobster, Panulirus argus. Cell Tissue Res 278:337-352.

Schoofs L, Vanden Broeck J, De Loof A (1993) The myotropic peptides of Locusta migratoria: structures, distribution, functions and receptors. Insect Biochem Mol Biol 23:859-881.

Schot LPC, Boer MM, Swaab DF, van Norden S (1981) Immunocytochemical demonstration of peptidergic neurons in the central nervous system of the pond snail Lymnea stagnalis with antisera raised to biologically active peptides of vertebrates. Cell Tissue Res 216:273-291.

Simmons LK, Schuetze SM, Role LW (1990) Substance P modulates single-channel properties of neuronal nicotinic acetylcholine receptors. Neuron 4:393-403.

Strausfeld NJ, Campos-Ortega JA (1977) Vision in insects: pathways possibly underlying neural adaptation and lateral inhibition. Science 195:894-897.

Strausfeld NJ, Nässel DR (1981) Neuroarchitecture of brain regions that subserve the compound eyes of crustacea and insects. In: Handbook of sensory physiology, Vol VII/6B (Autrum H, ed), pp 1-132. Berlin: Springer.

Sun XP, Supplisson S, Mayer E (1993) Chloride channels in myocytes from rabbit colon are regulated by a pertussis toxin-sensitive $\mathrm{G}$ protein. Am J Physiol 264:G774-G785.

Sweatt JD, Voltera A, Edmonds B, Karl KA, Siegelbaum SA, Kandel ER (1989) FMFRamide reverses protein phosphorylations produced by 5-HT and cAMP in Aplysia sensory neurons. Nature 342:275-278.

Takeuchi A, Takeuchi N (1966) On the permeability of the presynaptic terminal of the crayfish neuromuscular junction during synaptic inhibition and the action of aminobutyric acid. J Physiol (Lond) 183:433-449.

Vitzthum H, Homberg U (1998) Immunocytochemical demonstration of locustatachykinin-related peptides in the central complex of the locust brain. J Comp Neurol 390:455-469.

Wang-Bennett L, Glantz RM (1987) The functional organization of the crayfish lamina ganglionaris. I. Nonspiking monopolar cells. J Comp Physiol [A] 161:131-145.

Williamson S, Pompolo S, Furness JB (1996) GABA and nitric oxide synthase immunoreactivities are colocalized in a subset of inhibitory motor neurons of the guinea-pig small intestine. Cell Tissue Res 284:29-37.

Yamada K, Akasu T (1996) Substance P suppresses GABA receptor function via protein kinase $\mathrm{C}$ in primary sensory neurones of bullfrogs. J Physiol (Lond) 496:439-449.

Zalutsky R, Miller RF (1990) The physiology of substance P in the rabbit retina. J Neurosci 10:394-402.

Zufall F, Franke CH, Hatt H (1988) Acetylcholine activates a chloride channel as well as glutamate and GABA. J Comp Physiol [A] 163: $609-620$. 